\title{
Sleep Disorders Accompanying Migraine and Tension Headaches
}

\section{Migren ve Gerilim Tipi Baș Ağrısına Eșlik Eden Uyku Hastalıkları}

\author{
(1) Mehmet Hamamcı, ( S Seyhan Dumanlıdağ * \\ Bozok University Faculty of Medicine, Department of Neurology, Yozgat, Turkey \\ *Aksaray University Training and Research Hospital, Clinic of Neurology, Aksaray, Turkey
}

\begin{abstract}
Objective: This study aimed to investigate sleep disorders in patients with episodic migraines and tension-type headaches.

Materials and Methods: This study was conducted between June 15 2019, and December 15, 2019, at the neurology clinics of two different tertiary hospitals. The study included 100 healthy volunteers, 102 patients with episodic migraine, and 105 patients with episodic tensiontype headache. All participants were assessed using Beck Depression inventory (BDI), Beck Anxiety inventory (BAI), Epworth Sleepiness scale (ESS), Berlin Questionnaire, Insomnia Severity index (ISI), and Pittsburgh Sleep Quality index (PSQI). The presence and severity of Restless Legs syndrome (RLS) were evaluated according to the International RLS Study Group criteria.

Results: Patients with migraine and tension headaches had significantly higher BDI, BAI, ESS, ISI, and total PSQI scores compared with the control group. According to the Berlin Questionnaire, $8 \%$ of the healthy controls, $20.6 \%$ of patients with migraine, and $11.4 \%$ of patients with tension headache were at high risk for Sleep Apnea syndrome. RLS criteria were met by $3 \%$ of healthy controls, $9.8 \%$ of patients with migraine, and $6.7 \%$ of patients with tension headache. Subjective sleep quality, sleep disturbance, and daytime dysfunction scores were significantly higher in patients with migraine compared with those with tension headache. By contrast, sleep latency and sleep efficiency scores were significantly higher in patients with tension headache compared with those with migraine.

Conclusion: The study results indicated that migraines and tensiontype headaches have varying effects on sleep. Hence, for each of the headache types, sleep disorders should be examined under a broad spectrum, and each sleep disorder should be investigated separately. Keywords: Sleep quality, sleepiness, Obstructive Sleep Apnea syndrome, insomnia, obesity, anxiety, Restless Legs syndrome
\end{abstract}

Öz

Amaç: Bu çalışma epizodik migren ve epizodik gerilim tipi baş ağrısı olan hastalıklarda uyku bozukluklarının araştırılması amaçlandı.

Gereç ve Yöntem: Bu çalışma, 15 Haziran 2019 ve 15 Aralık 2019 tarihleri arasında, iki farklı üçüncü basamak hastanenin nöroloji kliniklerinde gerçekleştirildi. Çalışmaya 100 sağlıklı gönüllü, 102 epizodik migren hastası, 105 epizodik gerilim tipi baş ağrısı olan hasta dahil edildi. Tüm katılımcılara Beck Depresyon ölçeği (BDÖ), Beck Anksiyete ölçeği (BAÖ), Epworth Uykululuk ölçeği (EUÖ), Berlin Uyku anketi, Uykusuzluk Şiddeti indeksi (UŞI), Pittsburgh Kalite Uyku indeksi (PKUI) uygulandı. Huzursuz Bacaklar sendromu (HBS) varlığı ve şiddeti Uluslararası HBS Çalışma Grubu kriterlerine göre değerlendirildi.

Bulgular: Migren ve gerilim tipi baş ağrısı hastalarının BDÖ, BAÖ, EUÖ, UŞi ve toplam PKUI puanları kontrol grubuna göre anlamlı yüksekti. Berlin anketine göre sağlıklıların \%8'i, migren hastalarının \%20,6'sı, gerilim tipi baş ağrısı hastalarının \%11,4'ü yüksek Uyku Apne sendromu

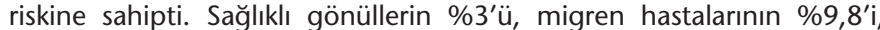
gerilim tipi baş ağrısı hastalarının \%6,7'si huzursuz bacak tanı kriterlerini karşıladı. Migren hastalarının öznel uyku kalitesi, uyku bozukluğu, gündüz işlev bozukluğu puanları gerilim tipi baş ağrısı hastalarından, gerilim tipi baş ağrısı hastalarının uyku latansı ve uyku etkinliği puanları migren hastalarından anlamlı yüksekti.

Sonuç: Bu sonuçlar migren ve gerilim tipi baş ağrısının uyku üzerinde farklı etkiler oluşturduğunu gösterdi. Her baş ağrısı tipi için uyku bozuklukları geniş bir yelpazede incelemeli ve her bir uyku bozukluğu ayrı ayrı sorgulanmalıdır.

Anahtar Kelimeler: Uyku kalitesi, uykululuk, Uyku Apne sendromu, uykusuzluk, obezite, anksiyete, Huzursuz Bacaklar sendromu 


\section{Introduction}

There is a strong and complex relationship between headaches and sleep. It is well known that sleep disorders lead to headache or induce primary headaches. However, headaches are also known to trigger or induce sleep disorders. Therefore, a "chicken and egg" causality dilemma emerges (1). Sleep has been known to play a therapeutic role in the ending of acute migraine attacks for a long time. Subsequently, doctors sometimes prescribe sleep-inducing drugs to treat migraines. Despite these widespread clinical observations and treatment goals, the relationship between sleep and headache has only drawn attention in recent times (2).

Tension-type headaches and migraines are the most common headache disorders, with prevalence of about $42 \%$ (3) and $12 \%$ (4), respectively. One meta-analysis demonstrated that both inadequate or excessive sleep may be associated with increased chronic disease-related mortality and morbidity (5). Evaluation of the high prevalence of data on migraine and tension-type headache in the literature together with the results of this metaanalysis once again draws attention to the significance of this comorbidity.

Depression and anxiety are well-known to disrupt sleep $(6,7)$. However, sleep disorders are accepted as a risk factor in the development or aggravation of medical disorders such as depression and anxiety (8). On the other hand, anxiety and depression are frequently encountered in patients with migraine and tension-type headache (9). At the same time, anxiety and depression are also known to trigger headaches $(9,10)$.

The term "sleep disorders" is now being addressed within an expanding spectrum that includes insomnia, Obstructive Sleep apnea, and poor sleep quality as well as other sleep disorders (1). When reviewing relevant literature, it is noteworthy that studies on sleep and headache usually examine a headache together with a sleep disorder $(1,11)$. For example, one study studied the relationship between migraine and Obstructive Sleep Apnea syndrome (OSAS) (12), another investigated migraine and sleep quality (13), while yet another examined excessive daytime sleepiness in those with migraine and tension-type headache (14). Therefore, this could be indicative that there is a need for studies that evaluate primary headaches together with several sleep disorders.

This study aimed to investigate the relationship between sleep disorders, depression, and anxiety in patients with episodic migraines and episodic tension-type headaches.

\section{Materials and Methods}

This cross-sectional case-control study was conducted simultaneously at the neurology clinics of two different tertiary hospitals between the dates of June 15, 2019 and December 15, 2019. The study was conducted in accordance with the principles of the Declaration of Helsinki and informed written consent was obtained from all participants. The study received ethics approval from the university's ethics committee (protocol no: 2017-KAEK-189_2019.05.29_14).

\section{Study Population}

This study included a total of 102 patients with episodic migraine and 105 patients with episodic tension-type headache between ages 18-65 who met the 2018 criteria of the International Headache Classification (15) as well as 100 healthy control group subjects without a diagnosis of headache.

Volunteers who experienced migraine or tension headaches for at least one year, who had at least primary education, mental capabilities to complete the questionnaires and comprehend the scope of the study, and who had not used regular medication (more than 5 per month) including migraine and tension headache prophylaxis participated in the study. Those with alcohol-substance and caffeine addiction, chronic physical illness, shift workers, pregnant and breastfeeding women, smokers, patients with neurological disorders other than episodic migraine and tension headache, and those with endocrine and systemic diseases were excluded from the study. The control group consisted of 100 healthy volunteers who were matched with the migraine and tension headache groups in terms of age and sex. The control group was also subjected to the exclusion criteria listed above. In addition, those diagnosed with headache or who experienced headache for any reason within the past six months were also excluded from the study. Detailed clinical history was taken from the participants. Systemic physical examinations and neurological examinations were performed. All patients were evaluated on days without headache. The number of migraine and tension-type headache episodes, duration of disease, and frequency of headaches were recorded. Height and weight were measured and Body Mass indexes were calculated. All participants were administered Beck Depression inventory (BDI), Beck Anxiety inventory (BAI), Epworth Sleepiness scale (ESS), Berlin questionnaire, Insomnia Severity index (ISI), and Pittsburgh Sleep Quality index (PSQI). Presence and severity of Restless Legs syndrome (RLS) was evaluated according to International RLS Study Group criteria.

\section{Evaluation Tools}

\section{Data Collection Form}

The data collection form was developed by the researchers for study purposes and included questions related to the life stories of the participants. It included general information of patient and control groups. The form was applied at initial admission and collected data including age, sex, marital status, education level, place of residence, level of income, habits, drugs used, and history of comorbid disease.

\section{Beck Depression Inventory}

The BDI was developed by Beck et al. (16) in order to evaluate bodily, emotional, and motivational symptoms observed in depression. Total score ranges between 0-63, in which 0-9 indicates minimal, 10-16 mild, 17-29 moderate, and 30-63 severe depression. The scale's Turkish validity and reliability study was conducted by Hisli et al. (17).

\section{Beck Anxiety Inventory}

BAl was developed by Beck et al. (18) to measure the person's frequency of anxiety symptoms. Total score ranges between 
0-63, in which 8-15 indicates mild anxiety, 16-25 moderate anxiety, and 26-63 severe anxiety. The scale's Turkish validity and reliability study was conducted by Ulusoy et al. (19).

\section{Pittsburgh Sleep Quality Index}

PSQI was developed by Buysse et al. (20). The scale consists of 18 questions comprising 7 components. These components consist of subjective sleep quality, sleep latency, sleep duration, habitual sleep efficiency, sleep disturbances, use of sleeping medication, and daytime dysfunction. Higher scores point to poor sleep quality and high level of sleep disorder. A total score of 5 or higher indicates poor clinical sleep quality. The Turkish validity and reliability study was conducted by Ağargün et al. (21).

\section{Epworth Sleepiness Scale}

This scale is used to measure daytime sleepiness. Total score of 10 and higher indicates excessive daytime sleepiness (22). The scale's Turkish validity and reliability study was conducted by Izci et al. (23).

\section{Berlin Questionnaire}

The Berlin Questionnaire was developed for OSAS screening. It contains a total of 10 questions in three categories. Each category is evaluated separately; positive results in two or more categories is considered high risk for OSAS (24).

\section{Insomnia Severity Index}

ISI, developed to determine the degree of insomnia symptoms, can be used in population screenings as well as in the clinical evaluation of insomnia. Score between 0-7 indicates no clinically significant insomnia, 8-14 mild, 15-21 moderate, and 22-28 severe insomnia (25). The Turkish validity and reliability study of the index was conducted by Boysan et al. (26) in 2010.

\section{Restless Legs Syndrome Evaluation}

RLS was evaluated according to International RLS Study Group diagnostic criteria which was revised in 2014 (27). The disease severity scale developed by the International RLS Study Group was used in patients determined to have RLS (28). The overall score reflects the severity of the disease. The maximum score is 40 and graded as 1-10 mild, 11-20 moderate, 21-30 severe, and $31-40$ very severe.

\section{Statistical Analysis}

Statistical analysis was performed using the SPSS ${ }^{\circ} 22.0$ (Statistical Package for Social Sciences, IBM Inc., Chicago, IL, USA) package program. Descriptive statistics of the data was analyzed. Kolmogorov-Smirnov test was used to assess normality distribution. Chi-square test was used to compare categorical variables. In data with normal distribution, ANOVA and post-hoc Turkey's test were used to compare the three groups. In data without normal distribution, Kruskal-Wallis test was used to compare the three groups and Mann-Whitney $U$ test was used for two-way comparisons when there was significant difference. Pearson correlation test was used for data with normal distribution, while Spearman correlation was used for data without normal distribution. P value less than 0.05 was considered statistically significant.

\section{Results}

There was no significant difference between the migraine group, tension headache group, and control group according to age and sex. Mean BMI was significantly higher in the migraine group compared to the control group. The sociodemographic and clinical characteristics of the migraine and headache patients are presented in Table 1.

While patients with migraine and tension-type headache had significantly higher anxiety and depression scores compared to the control group, there was no significant difference between the migraine and tension-type headache groups. ESS and ISI scores were significantly higher in the migraine and tensiontype headache groups compared to the control group, while there was no significant difference between the migraine and tension-type headache groups according to ESS and ISI scores. Based on the results of the Berlin questionnaire, migraine patients had higher OSAS risk compared to the control group. $\mathrm{BAI}, \mathrm{BDI}, \mathrm{ESS}, \mathrm{ISI}$, Berlin questionnaire scores and RLS rates and severities of the migraine and tension headache patients and the control group are displayed in Table 2.

According to PSQI scores, $37 \%$ of the control group, $69.6 \%$ of the migraine group, and $59 \%$ of the tension headache group had poor sleep quality. According to subcomponents of PSQI, migraine patients had higher rates of poor sleep quality, sleep disturbances, and daytime dysfunction compared to the tension headache group. Sleep latency and sleep efficiency

\begin{tabular}{|c|c|c|c|c|}
\hline & \begin{tabular}{|l|} 
Control \\
$(\mathrm{n}=100)$
\end{tabular} & \begin{tabular}{|l|} 
Migraine \\
$(\mathrm{n}=102)$
\end{tabular} & \begin{tabular}{|l|} 
Tension-type headache \\
$(\mathrm{n}=105)$
\end{tabular} & $p$ \\
\hline Age, (mean \pm SD) & $39.28 \pm 8.83$ & $38.26 \pm 9.94$ & $39.62 \pm 9.74$ & 0.566 \\
\hline $\begin{array}{l}\text { Sex } \\
\text { Female (n) \% } \\
\text { Male (n) \% }\end{array}$ & $\begin{array}{l}69(69) \\
31(31)\end{array}$ & $\begin{array}{l}72.5(74) \\
27.5(28) \\
\end{array}$ & \begin{tabular}{|l|}
$76.2(80)$ \\
$23.8(25)$ \\
\end{tabular} & 0.513 \\
\hline Education level & $9.09 \pm 3.54$ & $9.65 \pm 3.35$ & $9.16 \pm 3.25$ & 0.442 \\
\hline $\mathrm{BMI},($ mean $\pm \mathrm{SD})$ & $25.69 \pm 3.95$ & $27.18 \pm 4.7 \mathrm{a}$ & $26.26 \pm 4.11$ & $0.046^{*}$ \\
\hline Disease duration, years, median (IQR) & - & $4(7.25)$ & $6(9)$ & - \\
\hline Headache frequency, (n/month), median (IQR) & - & $4(3)$ & $6(5)$ & - \\
\hline
\end{tabular}


subcomponent scores were significantly worse in tension-type headache patients compared to migraine patients. Overall PSQI scores of the three groups and comparison of subscale scores are presented in Table 3.
The relationships between ESS, ISI, total PSQI, and Berlin questionnaire scores and age, $\mathrm{BMI}$, disease duration, headache frequency, $\mathrm{BDI}$, and $\mathrm{BAI}$ in migraine patients are presented in Table 4.

Table 2. Comparison of the three groups according to Beck Depression inventory, Beck Anxiety scale, Epworth Sleepiness scale, Berlin Questionnaire, and Insomnia Severity index scores and Restless Leg syndrome diagnoses

\begin{tabular}{|c|c|c|c|c|}
\hline & \begin{tabular}{|l|} 
Control \\
$(n=100)$
\end{tabular} & $\begin{array}{l}\text { Migraine } \\
(n=102)\end{array}$ & $\begin{array}{l}\text { Tension-type } \\
\text { headache }(n=105)\end{array}$ & $\mathbf{p}$ \\
\hline BDI, median (IQR) & $6(3.75)$ & $10(12.25)^{\mathrm{a}}$ & $10(12)^{\mathrm{a}}$ & $<0.001^{* *}$ \\
\hline BAI, median (IQR) & $6(3.75)$ & $10(11.5)^{\mathrm{a}}$ & $9(10)^{a}$ & $<0.001^{* *}$ \\
\hline ESS, median (IQR) & $4(5)$ & $8(9)^{a}$ & $7(6)^{\mathrm{a}}$ & $<0.001^{* *}$ \\
\hline$E S S \geq 10, \%(n)$ & $6(6)$ & $29.4(30)^{a}$ & $21(22)^{a}$ & $<0.001^{* *}$ \\
\hline Berlin Questionnaire, High risk, (n) \% & $8(8)$ & $20.6(21)^{a}$ & $11.4(12)$ & $0.024^{*}$ \\
\hline Restless Legs syndrome, \% (n) & $3(3)$ & $9.8(10)$ & $6.7(7)$ & 0.146 \\
\hline Restless Legs syndrome Severity (mean \pm SD) & $17.33 \pm 3.21$ & $21.30 \pm 5.77$ & $17.28 \pm 3.49$ & 0.208 \\
\hline
\end{tabular}

BDI: Beck Depression inventory, BAI: Beck Anxiety scale, ESS: Epworth Sleepiness scale, ISI: Insomnia Severity index, SD: Standard deviation, a: significantly high compared to the control group. Bold values represent significant findings at $\left.p<0.05 .{ }^{*}: p<0.005,{ }^{* *}: p<0.001\right)$

\begin{tabular}{|c|c|c|c|c|}
\hline & $\begin{array}{l}\text { Control } \\
(\mathrm{n}=100)\end{array}$ & \begin{tabular}{|l|}
$\begin{array}{l}\text { Migraine } \\
(n=102)\end{array}$ \\
\end{tabular} & $\begin{array}{l}\text { Tension-type headache } \\
(\mathrm{n}=105)\end{array}$ & $p$ \\
\hline PSQI total, median (IQR) & $3(5)$ & $8(5)^{\mathrm{a}}$ & $7(6)^{\mathrm{a}}$ & $<0.001^{* *}$ \\
\hline Subjective Sleep Quality, median (IQR) & $1(1)$ & $2(1)^{a, c}$ & $1(1)^{a}$ & $<0.001^{* *}$ \\
\hline Sleep latency, median (IQR) & $1(1)$ & $1(1.25)^{\mathrm{a}}$ & $2(1)^{a, b}$ & $<0.001^{* *}$ \\
\hline Sleep duration, median (IQR) & $0(1)$ & $1(1)^{\mathrm{a}}$ & $1(2)^{\mathrm{a}}$ & $0.001^{*}$ \\
\hline Habitual sleep efficiency, median (IQR) & $0(1)$ & $1(1)^{\mathrm{a}}$ & $1(2)^{a, b}$ & $<0.001^{* *}$ \\
\hline Sleep disturbance, median (IQR) & $1(1)$ & $1(1)^{a, c}$ & $1(0.5)^{\mathrm{a}}$ & $<0.001^{* *}$ \\
\hline Use of sleeping medications, median (IQR) & $0(0)$ & $0(0)$ & $0(0)$ & 0.083 \\
\hline Daytime Dysfunction, median (IQR) & $0(1)$ & $2(1)^{a, c}$ & $1(2)^{a}$ & $<0.001^{* *}$ \\
\hline Poor sleep quality, \%(n) & $37(37)$ & $69.6(71)^{a}$ & $59(62)^{a}$ & $<0.001^{*}$ \\
\hline
\end{tabular}

\begin{tabular}{|c|c|c|c|c|}
\hline & PSQI total score & ESS & ISI & \begin{tabular}{|l} 
Berlin questionnaire \\
(total of 3 categories)
\end{tabular} \\
\hline Age & $\begin{array}{l}\mathrm{r}=0.020 \\
\mathrm{p}=0.839\end{array}$ & $\begin{array}{l}r=0.170 \\
p=0.087\end{array}$ & $\begin{array}{l}r=0.169 \\
p=0.090\end{array}$ & $\begin{array}{l}\mathrm{r}=0.178 \\
\mathrm{p}=0.074\end{array}$ \\
\hline BMI & $\begin{array}{l}\mathrm{r}=0.071 \\
\mathrm{p}=0.481\end{array}$ & $\begin{array}{l}r=0.442 \\
p<0.001^{\text {** }}\end{array}$ & $\begin{array}{l}\mathrm{r}=0.087 \\
\mathrm{p}=0.383\end{array}$ & $\begin{array}{l}r=0.327 \\
p=0.001^{*}\end{array}$ \\
\hline Disease duration & $\begin{array}{l}\mathrm{r}=0.026 \\
\mathrm{p}=0.798\end{array}$ & $\begin{array}{l}r=0.049 \\
p=0.623\end{array}$ & $\begin{array}{l}r=0.107 \\
p=0.28\end{array}$ & $\begin{array}{l}r=-0.034 \\
p=0.731\end{array}$ \\
\hline Headache frequency & $\begin{array}{l}\mathrm{r}=0.290 \\
\mathrm{p}=0.003^{*}\end{array}$ & $\begin{array}{l}r=0.239 \\
p=0.016^{*}\end{array}$ & $\begin{array}{l}r=0.387 \\
p<0.001^{* *}\end{array}$ & $\begin{array}{l}r=0.101 \\
p=0.315\end{array}$ \\
\hline BDI & $\begin{array}{l}\mathrm{r}=0.442 \\
\mathrm{p}<0.001^{* *}\end{array}$ & $\begin{array}{l}\mathrm{r}=0.242 \\
\mathrm{p}=0.014^{\star}\end{array}$ & $\begin{array}{l}\mathrm{r}=0.338 \\
\mathrm{p}=0.001^{*}\end{array}$ & $\begin{array}{l}\mathrm{r}=0.069 \\
\mathrm{p}=0.489\end{array}$ \\
\hline BAI & $\begin{array}{l}\mathrm{r}=0.345 \\
\mathrm{p}<0.001^{* *}\end{array}$ & $\begin{array}{l}\mathrm{r}=0.243 \\
\mathrm{p}=0.041^{\text {** }}\end{array}$ & $\begin{array}{l}\mathrm{r}=0.215 \\
\mathrm{p}=0.030^{*}\end{array}$ & $\begin{array}{l}r=0.031 \\
p=0.756\end{array}$ \\
\hline
\end{tabular}


The relationships between ESS, ISI, total PSQI, and Berlin questionnaire scores and age, BMI, disease duration, headache frequency, BDI, and BAI in patients with tension-type headache are presented in Table 5.

\section{Discussion}

Despite the differences of etiopathogeneses in primary headaches, the hypothalamus plays a critical role in headache episodes $(29,30)$. At the same time, the hypothalamus is the main regulator of homeostatic mechanisms, including sleepwake cycles, indicating a common etiopathogenesis (31). However, there is a complex relationship between pain, sleep, and mental state with indistinguishable limits. Pain can disrupt sleep quality, while disturbance of sleep routine can induce pain, manifesting as depression and anxiety $(11,32,33)$. On the other hand, depression and anxiety can lead to sleep disorders and induce headaches $(6,7,9,10)$.

In our study, mean BMI values were found significantly higher in migraine patients compared to healthy control subjects. The higher prevalence of episodic migraine in obese individuals suggests that obesity and migraine may have a common etiologic factor $(34,35)$. A meta-analysis comprised of data of up to 300,000 participants reported $37 \%$ increased migraine risk in obese adults (36). Both obesity and migraine induce the release of proinflammatory cytokines and neuropeptides. Therefore, the inflammatory processes of migraine and obesity seems connected $(34,37)$. On the other hand, obesity is a factor also known to negatively affect sleep quality $(38,39)$. Obesity is also a significant risk factor for OSAS (40). Nonetheless, sleep duration and quality has been determined to affect the metabolic and endocrine systems, and that shortened sleep duration may cause weight gain and obesity by impairing the neurohormonal balance (41). The literature findings described above reflect the complex structure of the relationship between obesity, migraine, and sleep.
ESS scores were significantly higher in patients with migraine and tension-type headache compared to healthy control subjects. In addition, according to ESS scores, $29.4 \%$ of migraine patients, $21 \%$ of tension headache patients, and $6 \%$ of the control group had excessive daytime sleepiness. There was a weak correlation between ESS score and BMI and a very weak correlation between ESS scores and headache frequency, $\mathrm{BDI}$, and BAI scores in migraine patients. In patients with tension-type headache, there was a weak correlation between ESS score and BDI and BAI scores, and a very weak correlation between ESS score and BMI. Excessive daytime sleepiness is one of the most common symptoms in neurological disorders that can affect quality of life by increasing the risk of accidents and often affecting daily living activities (42). One casecontrol study of 100 episodic migraine patients compared to healthy controls showed that daytime sleepiness was higher in migraine patients than controls and daytime sleepiness was associated with migraine disability, sleep problems, and anxiety (43). In another study, excessive daytime sleepiness levels were significantly higher in tension headache patients compared to the control group, and reported excessive daytime sleepiness was associated with depression and anxiety (14). On the contrary, another study showed no excessive daytime sleepiness in migraine patients (44). One study that excluded comorbid states (anxiety, depression, and poor sleep quality) did not find a significant difference between migraine patients and healthy control in terms of excessive daytime sleepiness (45). Evaluation of information in the literature and the results of our study together suggest that the significant relationship between migraine and tension headache and excessive daytime sleepiness may be related to poor sleep quality, depression, and anxiety encountered in migraine and tension headache.

According to the results of the Berlin questionnaire in the study, $20.6 \%$ of migraine patients were at high risk for OSAS and this rate was significantly higher compared to the control

\begin{tabular}{|c|c|c|c|c|}
\hline & PSQI total score & ESS & ISI & $\begin{array}{l}\text { Berlin questionnaire } \\
\text { (total of } 3 \text { categories) }\end{array}$ \\
\hline Age & $\begin{array}{l}r=0.025 \\
p=0.796\end{array}$ & $\begin{array}{l}r=0.158 \\
p=0.108\end{array}$ & $\begin{array}{l}r=0.102 \\
p=0.073\end{array}$ & $\begin{array}{l}r=0.132 \\
p=0.180\end{array}$ \\
\hline BMI & $\begin{array}{l}r=0.010 \\
p=0.922\end{array}$ & $\begin{array}{l}r=0.206 \\
p=0.035^{\star}\end{array}$ & $\begin{array}{l}r=0.086 \\
p=0.135\end{array}$ & $\begin{array}{l}r=0.486 \\
p<0.001^{* *}\end{array}$ \\
\hline Disease duration & $\begin{array}{l}r=0.015 \\
p=0.880\end{array}$ & $\begin{array}{l}r=0.107 \\
p=0.277\end{array}$ & $\begin{array}{l}r=0.084 \\
p=0.230\end{array}$ & $\begin{array}{l}r=0.005 \\
p=0.959\end{array}$ \\
\hline Headache frequency & $\begin{array}{l}r=0.297 \\
p=0.002^{*}\end{array}$ & $\begin{array}{l}r=0.159 \\
p=0.104\end{array}$ & $\begin{array}{l}r=0.257 \\
p<0.001^{* *}\end{array}$ & $\begin{array}{l}r=0.085 \\
p=0.386\end{array}$ \\
\hline BDI & $\begin{array}{l}\mathrm{r}=0.547 \\
\mathrm{p}<0.001^{* *}\end{array}$ & $\begin{array}{l}r=0.469 \\
p<0.001^{* *}\end{array}$ & $\begin{array}{l}r=0.461 \\
p<0.001^{* *}\end{array}$ & $\begin{array}{l}r=0.132 \\
p=0.180\end{array}$ \\
\hline BAl & $\begin{array}{l}\mathrm{r}=0.366 \\
\mathrm{p}<0.001^{* *}\end{array}$ & $\begin{array}{l}r=0.284 \\
p=0.003^{*}\end{array}$ & $\begin{array}{l}\mathrm{r}=0.351 \\
\mathrm{p}<0.001^{* *}\end{array}$ & $\begin{array}{l}r=0.085 \\
p=0.390\end{array}$ \\
\hline
\end{tabular}


group. A significant positive correlation between total Berlin questionnaire scores and BMI was also found. However, headache frequency did not correlate with Berlin Questionnaire scores. OSAS patients usually have complaints of morning headaches $(11,46)$. Snoring, the cardinal symptom of OSAS, has been determined to be a risk factor for chronic migraine (47). On the other hand, a review of results from different epidemiological studies showed that there was no relationship between OSAS and migraine (48). In our study, the fact that $\mathrm{BMI}$ values were higher in the migraine group may indicate this finding is related to obesity. However, it should also be considered that vascular diseases and obesity are prevalent in both migraine and OSAS patients (46).

RLS criteria were met by $9.8 \%$ of migraine patients and $6.7 \%$ of tension headache patients. One meta-analysis reported high and heterogeneous prevalence of RLS (ranging between 8.7-39\%) in migraine patients (49). The underlying pathophysiology of high prevalence of RLS in migraine has been researched. Dopamine and iron imbalance as a common mechanism for both migraine and RLS has been proposed $(46,50)$. One study reported RLS prevalence of $6 \%$ in patients with tension-type headache (51). There are few studies on tension-type headache and RLS. Nevertheless, the etiology of high prevalence of restless leg prevalence in migraine and tension headache patients has not been fully explained. Further studies are needed to explain the underlying pathophysiology of this association.

In our study, the ISI scores of migraine patients and tension headache patients were significantly higher compared to the control group. In addition, there was a significant correlation between ISI scores and headache frequency, BAI, and BDI scores in both migraine and tension headache patients. One study reported increased risk of migraine and non-migraine headache in individuals experiencing insomnia, and in the same study also showed that insomnia affected the clinical manifestation of migraine (52). Insomnia was also reported to be a factor that triggers tension-type headache (53). These findings draw attention to the importance of this comorbidity. In our study, total PSQI scores were found significantly higher in migraine and tension headache patients compared to the control group. Subjective sleep quality, sleep disturbance, and daytime dysfunction scores were significantly higher in migraine patients compared to tension headache patients, while sleep latency and Sleep Efficiency scores were significantly higher in tension headache patients compared to migraine patients. There was also a significant correlation between total PSQI scores and $\mathrm{BAI}$ and $\mathrm{BDI}$ scores. Current studies on the pathogenesis of tension-type headache and migraine have focused on mechanisms leading to pain sensitivity. Potential factors that may affect sensitivity mechanisms including stress, depression, or sleep disorders all play a vital role: reducing nociceptive firing threshold and causing hyperalgesia (1). However, while both primary headache types show similar pathogenic mechanisms, the pathogenesis and clinical manifestations of the two headaches are different. For this reason, they may have different effects on different areas of sleep. Therefore, a better understanding of the various effects of tension-type headache and migraine on the components of sleep may help clinicians establish better and sufficient therapeutic programs. One study reported that severe sleep disorder was five times more prevalent in migraine patients and three times more prevalent in tension-type headache patients compared to individuals without headache (54). It was reported that poor sleep quality may trigger migraine episode (13) and that migraine patients experiencing poor sleep had greater frequency of headaches (55). Poor sleep quality was also indicated that it may be a risk factor for the chronification of episodic tension-type headache (56). Another publication also reported that poorer sleep quality may cause more frequent headaches in patients with tensiontype headaches (57). On the other hand, it is well-known that depression and anxiety disrupt sleep, therefore researching this comorbidity is vital $(7,58)$. Evaluation of the results of our study together with information from the literature indicates that treatment of sleep disorders may have a positive effect on headache treatment. In addition, sleep disorder screening should be considered in all patients with headache. Sleep questionnaires can be used for these screenings. This situation may be considered when managing treatment of patients with positive screening results. Patients with positive screening results may also be referred to a sleep specialist.

\section{Study Limitations}

The main limitation of our study was that it did not include polysomnography and actigraphy evaluation. However, double-center study design, and concomitant evaluation of migraine and tension-type headache patients, as well as the use of multiple sleep questionnaires, could be considered the strengths of our study.

\section{Conclusion}

A strong relationship was determined between migraine and tension headaches and sleep disorders. However, reverse causality could not be ruled out; sleep disorders may lead to headaches or headaches may be the cause of sleep disorders. The cause of this coexistence may be common pathophysiology. Narrow statements that a headache patient has or does not have a sleep disorder should be avoided. This is because in the past, it was simply stated that there was or wasn't a sleep disorder, while now the term "sleep disorders" encompasses an ever-expanding spectrum, including insomnia, obstructive sleep apnea, poor sleep quality as well as other sleep disorders. Behavioral therapy has shown positive effects on headache (59) and sleep disorders (60). This information indicates that there is a need for results of behavioral therapy studies on the coexistence of headaches and sleep disorders.

Acknowledgments: We express our sincere appreciation to the patients with headache and the healthy volunteers who participated in this study.

\section{Ethics}

Ethics Committee Approval: The University School of Medicine Ethics Committee approved the study protocol (protocol no: 2017-KAEK-189_2019.05.29_14) 
Informed Consent: All of the participants provided written informed consent.

Peer-review: Internally peer-reviewed.

\section{Authorship Contributions}

Concept: M.H., Design: M.H., S.D., Data Collection or Processing: M.H., S.D., Analysis or Interpretation: M.H., Literature Search: M.H., S.D., Writing: M.H.

Conflict of Interest: No conflict of interest was declared by the authors.

Financial Disclosure: The authors declared that this study received no financial support.

\section{References}

1. Fernández-de-las-Peñas C, Fernández-Muñoz Jl, Palacios-Ceña M, Parás-Bravo P, Cigarán-Méndez M, Navarro-Pardo E. Sleep disturbances in tension-type headache and migraine. Ther Adv Neurol Disord 2018;11:1756285617745444.

2. Vgontzas A, Pavlovic JM. Sleep disorders and migraine: Review of literature and potential pathophysiology mechanisms. Headache 2018;58:1030-9.

3. Ferrante T, Manzoni GC, Russo M, Camarda C, Taga A, Veronesi L, Pasquarella C, Sansebastiano G, Torelli P. Prevalence of tension-type headache in adult general population: the PACE study and review of the literature. Neurol Sci 2013;34:137-8.

4. Woldeamanuel YW, Cowan RP. Migraine affects 1 in 10 people worldwide featuring recent rise: a systematic review and metaanalysis of community-based studies involving 6 million participants. J Neurol Sci 2017;372:307-15.

5. Cappuccio FP, D’Elia L, Strazzullo P, Miller MA. Sleep duration and allcause mortality: a systematic review and meta-analysis of prospective studies. Sleep 2010;33:585-92.

6. Hamamcı M, Hacimusalar Y, Karaaslan O, Inan LE. Evaluation of sleep quality in spouses of people with epilepsy. Epilepsy Behav 2019;94:233-8.

7. Inanç L, Altıntaş M, Semiz ÜB. The Relation of Sleep Quality to Depression and Anxiety in Obsessive Compulsive Disorder. J Turk Sleep Med 2018;5:1-5.

8. Karaaslan Ö. Obstrüktif Uyku Apne Sendromu ve Psikiyatri. Bozok Medical Journal 2018;8:34-8.

9. Sayılgan N, Domaç FM, Güleç H. Migren ve gerilim tipi baş ağrısı tanılı bireylerde psikiyatrik eştanı ve yaşam kalitesi ile ilişkisi: ön çalışma. Cukurova Medical Journal 2019;44:44-51.

10. Mongini F, Rota E, Deregibus A, Ferrero L, Migliaretti G, Cavallo F, Mongini T, Novello A. Accompanying symptoms and psychiatric comorbidity in migraine and tension-type headache patients. I Psychosom Res 2006;61:447-51.

11. Hamamcı M, Alpua M, Ergün U, Inan LE. Obstrüktif uyku apne sendromu ve nöroloji. Bozok Tıp Dergisi 2018;8:20-5.

12. Kristiansen HA, Kværner KJ, Akre H, Øverland B, Russell MB. Migraine and sleep apnea in the general population. J Headache Pain 2011;12:55-61.

13. Lin YK, Lin GY, Lee JT, Lee MS, Tsai CK, Hsu YW, Lin YZ, Tsai YC, Yang FC. Associations between sleep quality and migraine frequency: a crosssectional case-control study. Medicine (Baltimore) 2016;95:e3554.

14. Demir AB, Karli N. A Survey Study to Investigate the Relationship of Sleep Disorders, Depression and Anxiety in Headache Patients. J Turk Sleep Med 2018;5:24-7.

15. No authors listed. Headache classification committee of the international headache society (IHS) the international classification of headache disorders. Cephalalgia. 2018;38:1-211.
16. Beck AT, Ward CH, Mendelson M, Mock J, Erbaugh J. An inventory for measuring depression. Arch Gen Psychiatry 1961;4:561-71.

17. Hisli N. Beck Depresyon Envanterinin geçerliği üzerine bir çalışma. Türk Psikoloji Dergisi 1988;6:118-22.

18. Beck AT, Epstein N, Brown G, Steer RA. An inventory for measuring clinical anxiety: psychometric properties. J Consult Clin Psychol 1988;56:893-7.

19. Ulusoy M, Sahin NH, Erkmen H. Turkish version of the Beck anxiety inventory: psychometric properties. Journal of Cognitive Psychotherapy 1998;12:163-72.

20. Buysse DJ, Reynolds 3rd CF, Monk TH, Berman SR, Kupfer DJ. The Pittsburgh Sleep Quality Index: a new instrument for psychiatric practice and research. Psychiatry Res 1989;28:193-213.

21. Ağargün M. Pittsburgh uyku kalitesi indeksinin geçerliği ve güvenirliği. Türk Psikiyatri Dergisi 1996;7:107-15.

22. Johns MW. A new method for measuring daytime sleepiness: the Epworth sleepiness scale. Sleep 1991;14:540-5.

23. Izci B, Ardic S, Firat H, Sahin A, Altinors M, Karacan I. Reliability and validity studies of the Turkish version of the Epworth Sleepiness Scale. Sleep Breath 2008;12:161-8.

24. Abrishami A, Khajehdehi A, Chung F. A systematic review of screening questionnaires for obstructive sleep apnea. Can J Anesth 2010;57:423-38.

25. Bastien $\mathrm{CH}$, Vallières $\mathrm{A}$, Morin $\mathrm{CM}$. Validation of the Insomnia Severity Index as an outcome measure for insomnia research. Sleep Med 2001;2:297-307.

26. Boysan M, Güleç M, Beşiroğlu L, Kalafat T. Uykusuzluk Şiddeti Indeksi'nin Türk örneklemindeki psikometrik özellikleri. Anadolu Psikiyatri Dergisi 2010;11:248-52.

27. Allen RP, Picchietti DL, Garcia-Borreguero D, Ondo WG, Walters AS, Winkelman JW, Zucconi M, Ferri R, Trenkwalder C, Lee HB, International Restless Legs Syndrome Study Group. Restless legs syndrome/WillisEkbom disease diagnostic criteria: updated International Restless Legs Syndrome Study Group (IRLSSG) consensus criteria-history, rationale, description, and significance. Sleep Med 2014;15:860-73.

28. Walters AS, LeBrocq C, Dhar A, Hening W, Rosen R, Allen RP, Trenkwalder C; International Restless Legs Syndrome Study Group. Validation of the International Restless Legs Syndrome Study Group. Sleep Med 2003;4:121-32.

29. Maniyar FH, Sprenger T, Monteith T, Schankin C, Goadsby PJ. Brain activations in the premonitory phase of nitroglycerin-triggered migraine attacks. Brain 2013;137:232-41.

30. Holland PR. Biology of neuropeptides: Orexinergic involvement in primary headache disorders. Headache 2017;57(Suppl 2):76-88.

31. Holland PR. Headache and sleep: shared pathophysiological mechanisms. Cephalalgia 2014;34:725-44.

32. Frohnhofen H. Pain and sleep: A bidirectional relationship. Z Gerontol Geriatr 2018;51:871-4.

33. de Oliveira DL, Hirotsu C, Tufik S, Andersen ML. The interfaces between vitamin D, sleep and pain. J Endocrinol 2017;234:23-36.

34. Andreeva VA, Galan P, Julia C, Fezeu L, Hercberg S, Kesse-Guyot E. A systematic literature review of observational studies of the bidirectional association between metabolic syndrome and migraine. Diabetes Metab 2017;45:11-18.

35. Di Renzo L, Cammarano A, De Lorenzo A. The missclassification of obesity affects the course of migraine. J Headache 2018;19:63.

36. Gelaye B, Sacco S, Brown W], Nitchie HL, Ornello R, Peterlin BL. Body composition status and the risk of migraine: A Meta-analysis. Neurology 2017;88:1795-804.

37. Peterlin $B L$, Rosso AL, Williams MA, Rosenberg JR, Haythornthwaite JA, Merikangas KR, Gottesman RF, Bond DS, He JP, Zonderman AB. 
Episodic migraine and obesity and the influence of age, race, and sex. Neurology 2013;81:1314-21.

38. Ferranti R, Marventano S, Castellano S, Giogianni G, Nolfo F, Rametta $S$, Matalone M, Mistretta A. Sleep quality and duration is related with diet and obesity in young adolescent living in Sicily, Southern Italy. Sleep Sci 2016;9:117-22.

39. Fatima Y, Doi S, Mamun AA. Sleep quality and obesity in young subjects: A Meta-analysis. Obesity Rev 2016;17:1154-66.

40. Ertekin YH, Şahin MK, Yarış F. Obezite ve obstrüktif uyku apne sendromu. Turkiye Klinikleri Family Medicine-Special Topics 2015;6:60-4.

41. Taheri S, Lin L, Austin D, Young T, Mignot E. Short sleep duration is associated with reduced leptin, elevated ghrelin, and increased body mass index. PLoS Med 2004;1:62.

42. Maestri M, Romigi A, Schirru A, Fabbrini M, Gori S, Bonuccelli U, Bonanni E. Excessive daytime sleepiness and fatigue in neurological disorders. Sleep Breath 2019:1-12.

43. Barbanti P, Fabbrini G, Aurilia C, Vanacore N, Cruccu G. A casecontrol study on excessive daytime sleepiness in episodic migraine. Cephalalgia 2007;27:1115-9.

44. Gori S, Lucchesi C, Baldacci F, Bonuccelli U. Preferential occurrence of attacks during night sleep and/or upon awakening negatively affects migraine clinical presentation. Funct Neurol 2015;30:119-23.

45. Kim J, Cho SJ, Kim WJ, Yang KI, Yun CH, Chu MK. Excessive daytime sleepiness is associated with an exacerbation of migraine: $A$ population-based study. J Headache Pain 2016;17:62.

46. Ferini-Strambi L, Galbiati A, Combi R. Sleep disorder-related headaches. Neurol Sci 2019;40:107-13.

47. Scher Al, Midgette LA, Lipton RB. Risk factors for headache chronification. Headache 2008;48:16-25.

48. Russell MB, Kristiansen HA, Kværner KJ. Headache in sleep apnea syndrome: epidemiology and pathophysiology. Cephalalgia 2014;34:752-5.

49. Schürks $M$, Winter A, Berger $K$, Kurth T. Migraine and restless legs syndrome: a systematic review. Cephalalgia 2014;34:777-94.
50. Dauvilliers Y, Winkelmann J. Restless legs syndrome: update on pathogenesis. Curr Opin Pulm Med 2013;19:594-600.

51. Chung PW, Cho SJ, Kim W], Yang KI, Yun CH, Chu MK. Restless legs syndrome and tension-type headache: a population-based study. I Headache Pain 2017; 18:47.

52. Kim J, Cho S-J, Kim W-J, Yang KI, Yun C-H, Chu MK. Impact of migraine on the clinical presentation of insomnia: a populationbased study. J Headache Pain 2018;19:86.

53. Martin PR, MacLeod C. Behavioral management of headache triggers: Avoidance of triggers is an inadequate strategy. Clin Psychol Rev 2009;29:483-95.

54. Ødegård SS, Engstrøm M, Sand T, Stovner LJ, Zwart JA, Hagen K. Associations between sleep disturbance and primary headaches: the third Nord-Trøndelag Health Study. J Headache Pain 2010;11:197-206.

55. Zhu Z, Fan X, Li X, Tan G, Chen L, Zhou J. Prevalence and predictive factors for poor sleep quality among migraineurs in a tertiary hospital headache clinic. Acta Neurol Belg 2013;113:229-35.

56. Rains JC, Davis RE, Smitherman TA. Tension-type headache and sleep. Curr Neurol Neurosci Rep. 2015;15:520.

57. Kikuchi H, Yoshiuchi K, Yamamoto Y, Komaki G, Akabayashi A. Does sleep aggravate tension-type headache?: An investigation using computerized ecological momentary assessment and actigraphy. Biopsychos Med 2011;5:10.

58. Bobdey M, Fineberg N, Gale TM, Patel A, Davies HA. Reported sleep patterns in obsessive compulsive disorder (OCD). Int J Psychiatry Clin Pract 2002;6:15-21.

59. Inan LE. Baş Ağrısı Tedavisinde Bilişsel Davranışcı Tedaviler. Turkiye Klinikleri J Neurol-Special Topics 2018;11:125-8.

60. Wu JQ, Appleman ER, Salazar RD, Ong JC. Cognitive Behavioral Therapy for Insomnia Comorbid With Psychiatric and Medical Conditions: A Meta-analysis. JAMA Intern Med 2015;175:1461-72. 